\title{
Interannual and Intraseasonal Variability in Fine Mode Particles over Delhi: Influence of Meteorology
}

\author{
S. Tiwari, ${ }^{1}$ D. S. Bisht, ${ }^{1}$ A. K. Srivastava, ${ }^{1}$ G. P. Shivashankara, ${ }^{2}$ and R. Kumar ${ }^{3}$ \\ ${ }^{1}$ Indian Institute of Tropical Meteorology (Branch), Prof Ramnath Vij Marg, New Delhi 110060, India \\ ${ }^{2}$ Department of Environmental Engineering, P. E. S. College of Engineering, Mandya, Karnataka 571401, India \\ ${ }^{3}$ Sharda University, Knowledge Park III, Greater Noida 201306, India
}

Correspondence should be addressed to D. S. Bisht; dsbisht@tropmet.res.in

Received 23 May 2013; Revised 26 September 2013; Accepted 3 October 2013

Academic Editor: D. M. Chate

Copyright (C) 2013 S. Tiwari et al. This is an open access article distributed under the Creative Commons Attribution License, which permits unrestricted use, distribution, and reproduction in any medium, provided the original work is properly cited.

\begin{abstract}
Fine mode particles (i.e., $\mathrm{PM}_{2.5}$ ) were collected at Delhi, India, for three consecutive years from January 2007 to December 2009 and were statistically analyzed. Daily mean mass concentration of $\mathrm{PM}_{25}$ was found to be $108.81 \pm 75.5 \mu \mathrm{g} \mathrm{m}^{-3}$ ranged from 12 to $367.9 \mu \mathrm{g} \mathrm{m}^{-3}$, which is substantially higher than the Indian National Ambient Air Quality Standards (NAAQS). Among the measurements, $\sim 69 \%$ of $\mathrm{PM}_{2.5}$ samples exceeded $24 \mathrm{~h}$ Indian NAAQS of $\mathrm{PM}_{2.5}$ level $\left(\mu \mathrm{g} \mathrm{m}^{-3}\right)$; however, $\sim 85 \%$ samples exceeded its annual level $\left(40 \mu \mathrm{g} \mathrm{m}^{-3}\right)$. Approximately $30 \%$ of PM2.5 mass was in the range of $40-80 \mu \mathrm{g} \mathrm{m}^{-3}$, indicating abundance of fine particles over Delhi. Intraseasonal variability of $\mathrm{PM}_{2.5}$ indicates highest mass concentration during postmonsoon (154.31 \pm $\left.81.62 \mu \mathrm{g} \mathrm{m}^{-3}\right)$, followed by winter $\left(150.81 \pm 74.65 \mu \mathrm{g} \mathrm{m}^{-3}\right)$, summer $\left(70.86 \pm 29.31 \mu \mathrm{g} \mathrm{m}^{-3}\right)$, and monsoon $\left(45.06 \pm 18.40 \mu \mathrm{g} \mathrm{m}^{-3}\right)$. In interannual variability, it was seen that in 2008, the fine mode particle was $\sim 23 \%$ and $\sim 36 \%$ higher as compared to 2007 and 2009 , respectively. Significantly negative correlation was found between $\mathrm{PM}_{2.5}$ and temperature $(-0.59)$ as well as wind speed (-0.38). Higher concentration of $\mathrm{PM}_{2.5}\left(173.8 \mu \mathrm{g} \mathrm{m}^{-3}\right)$ was observed during calm conditions whereas low concentration $\left(79.18 \mu \mathrm{g} \mathrm{m}^{-3}\right)$ was observed when wind speed was $>5 \mathrm{Km} / \mathrm{hr}$. In winter, greater exposure risk is expected, as the pollutant often gets trapped in lower atmosphere due to stable atmospheric conditions.
\end{abstract}

\section{Introduction}

Aerosols, suspended in the atmosphere, are distributed through turbulence and direct atmospheric transport of air masses. These aerosols interact with Earth's energy budget, directly as well as indirectly. As a direct effect, aerosols scatter, absorb, and reflect solar energy that enters and exits in the Earth's atmosphere, while as an indirect effect, they altered the size, shape, and location of clouds and affected the precipitation in lower atmosphere [1-4]. Apart from this, atmospheric aerosols, especially fine particles, have received much attention during the last two decades due to their potential adverse impacts on human health and agricultural production. Particulate matters with aerodynamic diameters less than $2.5 \mu \mathrm{m}$ (i.e., $\mathrm{PM}_{2.5}$ ), called fine particles, have especially been found to be associated with increasing respiratory illness, carcinogens [5], asthma [6], and ultimately in increasing the number of premature deaths [7-9]. Many epidemic studies have linked airborne concentrations of $\mathrm{PM}_{2.5}$ and $\mathrm{PM}_{10}$ with a variety of health problems, including morbidity and mortality [10].

Due to industrial and population growth, increased transportation system, burning of fossil fuel, high rate of urbanizations, and migrations are unavoidable in a developing country. India is the world's seventh largest country, second to China in its population. Rapid growth in megacities, especially in Delhi and Mumbai, is a cause of concern for air quality. Note that Delhi is the fourth most polluted and the seventh most populous metropolis in the world. According to a local survey, $30 \%$ of Delhi's population was found suffering from respiratory disorders due to air pollution, and this number is about 12 times the national average [11]. Over the station, the presence of industrial activity and traffic emissions are likely to be the most important sources of air pollutants. Increasing particulate matter has already noted to affect human health in megacities $[12,13]$. As $\mathrm{PM}_{2.5}$ 
particles have relatively large surface to volume ratio and longer residence times in the atmosphere, they possess a higher proportion of persistent organic compounds than larger particles [14]. In addition to this, high levels of $\mathrm{PM}_{2.5}$ have been associated with amenity problems such as visibility degradation associated with haze [15].

The problem of pollution is not only the issue for Delhi, but also it is the case for several megacities of the entire world. Some studies on air quality assessment in Delhi have been carried out for PM emissions, effect of CNG regulations, air toxicity, and air quality index [16-18]. According to these studies, the transport sector of Delhi shares $\sim 72 \%$ of the total airborne pollutants $[16,19]$; however, major sources of air pollution in Delhi are emissions from vehicles (67\%), coal based thermal power plants (13\%), industrial units (12\%), and domestic exhaust (8\%). In 1991, the air pollutants daily emission loads over Delhi were $\sim 1,450$ metric tons (http://envfor.nic.in/divisions/cpoll/delpolln.html), which is still in the higher range exceeding prescribed standards of the World Health Organization [20]. The magnitude and urgency of the problem as a global environmental issue need a systematic understanding of the potential causes of pollution and their contribution to air quality. Mostly, in megacities, the main sources of fine particles are the combustion of fossil fuels from automobiles, construction equipments (mobile sources), furnaces, and power plants (stationary sources), where such particles are produced by combustion processes and mixed in the ambient air by mechanical processes $[13,21]$.

In the present study, fine mode particles (i.e., $\mathrm{PM}_{2.5}$ mass concentrations) were obtained from Central Pollution Control Board (CPCB) during the period from January 2007 to December 2009 in Delhi. The observed aerosol data was analyzed and presented in the present study with objectives (i) to assess interannual and intraseasonal variability of $\mathrm{PM}_{2.5}$ mass concentration over Delhi and its possible sources and (ii) to understand the effect of ambient meteorological parameters on aerosol formation and existence during different atmospheric conditions.

\section{Data Collection and Sampling Site}

Delhi, situated between $28^{\circ} 21^{\prime} 17^{\prime \prime}$ to $28^{\circ} 53^{\prime}$ latitude and $76^{\circ} 20^{\prime} 37^{\prime \prime}$ to $77^{\circ} 20^{\prime} 37^{\prime \prime}$ longitude with height of $\sim 218$ meter above mean sea level, is around $160 \mathrm{~km}$ away in the south from the southern part of the Himalayas. It is bounded by the Thar desert of Rajasthan in the west, plains of central India in the south, and Indo-Gangetic Plains (IGP) in the east. The area of the city is $1,483 \mathrm{~km}^{2}$ with $\sim 18$ million inhabitants. It experiences severe weather conditions between different seasons from hot and humid weather in summer to cold and dry weather in winter [22]. During the whole year, the prevailing wind was found to be easterly, northerly, and northwesterly, and to be strongest wind was in summer. Apart from such swings of weather in annual cycle, the whole northern part of India, especially the IGP, experiences thick foggy conditions during winter with lower boundary layer. More details about the station and the meteorological conditions are discussed elsewhere [23].

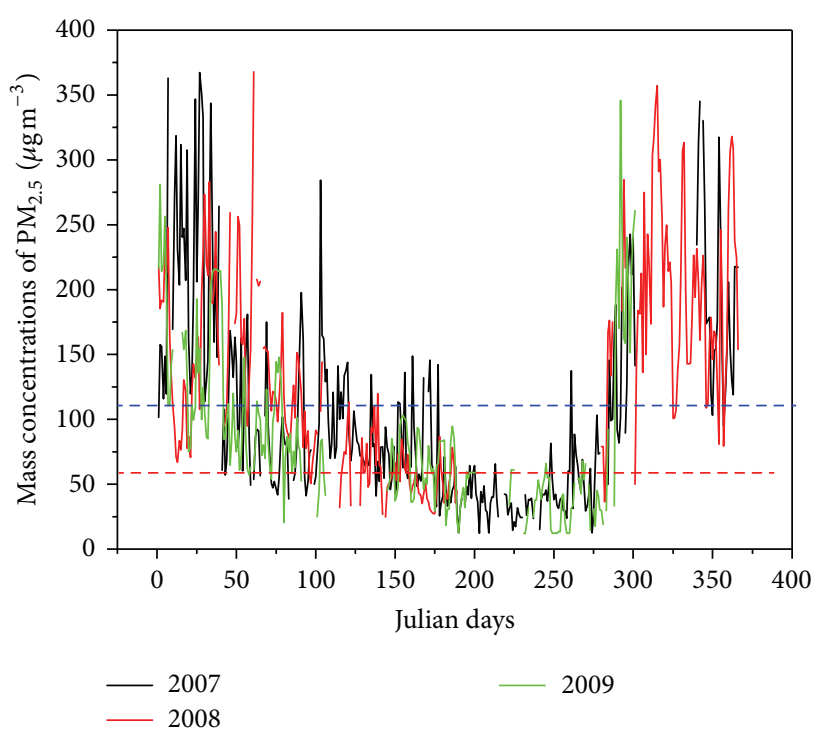

FIGURE 1: Day to day variability of mass concentrations of $\mathrm{PM}_{2.5}$, during 2007 to 2009 (blue dash line-mean concentration of $\mathrm{PM}_{2.5}$; red dash line-NAAQS).

Hourly mass concentrations of $\mathrm{PM}_{2.5}$ were collected for a period of three years from January 2007 to December 2009 which was monitored by CPCB (http://www.cpcb.nic.in/) at the Income Tax Office (ITO) intersection. CPCB is an independent governmental body which is responsible for monitoring the pollution levels at different environments across the country, including Delhi, under its National Ambient Air Quality Monitoring Network (NAAQMN). The sampling site is one of the highest traffic intersection zones, and a thermal power plant (747 MW) called "Indraprastha Thermal Power station" is located at about $500 \mathrm{~m}$ in the southeast azimuth. Further, the corresponding ambient meteorological parameters such as temperature, relative humidity $(\mathrm{RH})$, and wind speed (WS) were collected from the India Meteorological Department (http://www.imd.gov.in/), Lodhi Road.

\section{Results and Discussion}

3.1. Temporal Variability in Fine $\left(P M_{2.5}\right)$ Mode Particle. Day to day variability in mass concentrations of fine mode particle $\left(\mathrm{PM}_{2.5}\right)$ during the study period from January 2007 to December 2009 was plotted and depicted in Figure 1. The daily mean mass concentration of $\mathrm{PM}_{2.5}$ over Delhi during the study period was $108.81 \pm 75.5 \mu \mathrm{g} \mathrm{m}^{-3}$ that ranged from 12 to $367.9 \mu \mathrm{g} \mathrm{m}^{-3}$ which is substantially higher and far in excess of their annual averages stipulated by the Indian National Ambient Air Quality Standards (NAAQS; http://cpcb.nic.in/ National_Ambient_Air_Quality_Standards.php; $40 \mu \mathrm{g} \mathrm{m}^{-3}$ ) and the US National Ambient Air Quality Standards (http:// www.epa.gov/air/criteria.html; US NAAQS; $15 \mu \mathrm{gm}^{-3}$ ). During the study period, $\sim 69 \% \mathrm{PM}_{2.5}$ samples were found to exceed the $24 \mathrm{~h}$ limit of NAAQS for $\mathrm{PM}_{2.5}$ standard $\left(60 \mu \mathrm{g} \mathrm{m}^{-3}\right)$. Mass concentrations of $\mathrm{PM}_{2.5}$ show considerable 


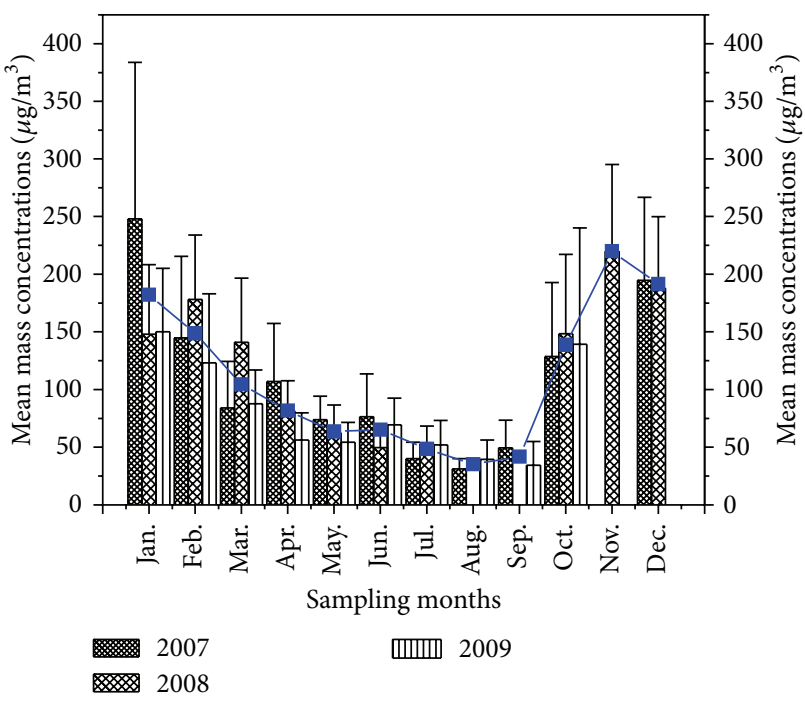

Figure 2: Yearwise monthly mean mass concentrations of $\mathrm{PM}_{2.5}$, during 2007 to 2009.

day to day variability, with the lowest value of $12 \mu \mathrm{g} \mathrm{m}^{-3}$ (on 18th August 2009) and the highest of $368 \mu \mathrm{g} \mathrm{m}^{-3}$ (on 1st March 2008), which could be due to the meteorological effect.

Interannual monthly mean mass concentrations of $\mathrm{PM}_{2.5}$ and its standard deviation during 2007 to 2009 were plotted and shown in Figure 2. Monthly mass concentrations of $\mathrm{PM}_{2.5}$ were observed to be in the following order: January $>$ February $>$ October $>$ April $>$ March $>$ June $>$ May $>$ September $>$ July $>$ August (2007), November $>$ December $>$ February $>$ October $>$ January $>$ March $>$ April $>$ May $>$ June $>$ July (2008), and December $>$ January $>$ October $>$ February $>$ March $>$ June $>$ April $>$ May $>$ July $>$ August $>$ September (2009). On the basis of monthly analysis, $\mathrm{PM}_{2.5}$ indicates the highest concentrations in winter and postmonsoon months. Also, we analyzed interannual variation of fine mode particles and were found the highest value during 2008 (135.44 \pm $77 \mu \mathrm{g} \mathrm{m}^{-3}$, varying from 12.0 to $367.9 \mu \mathrm{g} \mathrm{m}^{-3}$ ) followed by $2007\left(103.7 \pm 77.5 \mu \mathrm{g} \mathrm{m}^{-3}\right.$, varying from 12.2 to $\left.367.9 \mu \mathrm{g} \mathrm{m}^{-3}\right)$ and $2009\left(87.1 \mu \mathrm{g} \mathrm{m}^{-3}\right.$, varying from 12.0 to $\left.345.9 \mu \mathrm{g} \mathrm{m}^{-3}\right)$. In 2008 , the fine mode particle was higher by $\sim 23 \%$ and $36 \%$ as compared to 2007 and 2009, respectively, which could be due to synoptic meteorological changes over the station (see Section 3.2). Intraseasonal variability of mass $\mathrm{PM}_{2.5}$ was studied and shown in Figure 3. On the basis of annually season, the highest mass $\mathrm{PM}_{2.5}$ concentrations were during postmonsoon $\left(154.31 \pm 81.62 \mu \mathrm{g} \mathrm{m}^{-3}\right)$ followed by winter $\left(150.81 \pm 74.65 \mu \mathrm{g} \mathrm{m}^{-3}\right)$, summer $\left(70.86 \pm 29.31 \mu \mathrm{g} \mathrm{m}^{-3}\right)$, and monsoon $\left(45.06 \pm 18.40 \mu \mathrm{g} \mathrm{m}^{-3}\right)$. In overall, the lower mass concentration of fine particle was observed during monsoon due to washout effect, whereas the higher concentration was during winter due to low level inversion. $\mathrm{PM}_{2.5}$ concentrations during monsoon in 2007 and 2009 were nearly equal to the annual mean NAAQS except in $2008\left(53.13 \mu \mathrm{g} \mathrm{m}^{-3}\right)$; however, it was approximately four times higher during

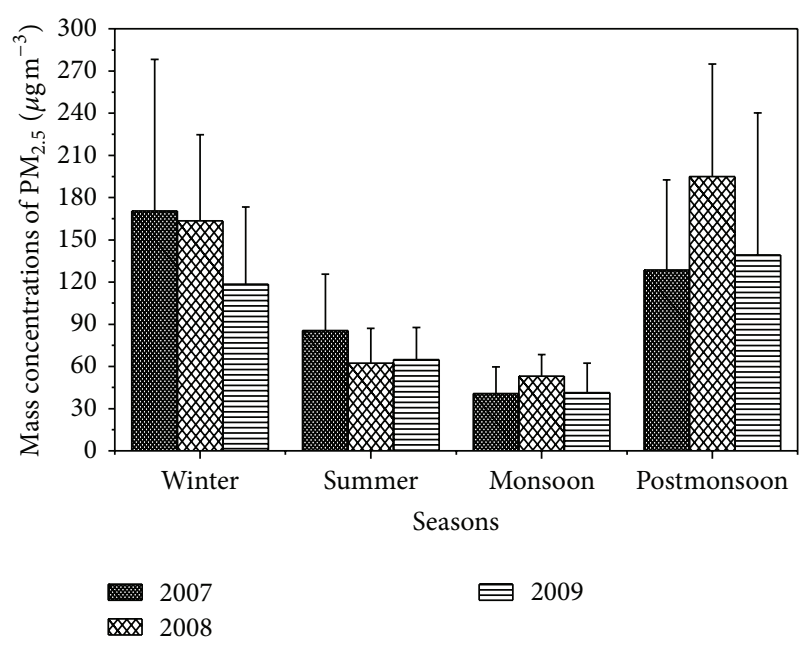

FIGURE 3: Seasonal variation of mass $\mathrm{PM}_{2.5}$ concentrations during study period over Delhi.

postmonsoon and winter whereas during summer, it was approximately double the NAAQS.

Very high mass concentration of $\mathrm{PM}_{2.5}$ during winter and postmonsoon is basically due to meteorological and emission effects $[24,25]$. The mixing height is observed to be lower due to low temperature and calm winds during these periods. On the other hand, burning of fire crackers during Deepawali festival, which is generally celebrated in the last week of October or in the first week of November every year all over India, is another important cause of generation of particulate matters during postmonsoon season [2629]. Minima were observed during monsoon season due to washout effect [24]. Bach et al. [30] reported an increase in total suspended particulate matters (TSPM) on an average by $300 \%$ at 14 locations; however, they also reported at one location that, due to fireworks on New Year's Eve, the lung penetrating size ranges particles increases up to $700 \%$. Increase in particle number is witnessed in the accumulation mode range $(>100 \mathrm{~nm})$ during the Millennium Fireworks in Leipzig, Germany [31]. Further, Liu et al. [32] reported the chemical composition and particle size of typical firework mixtures. An enhancement in $\mathrm{PM}_{2.5}$ up to 6 times and $\mathrm{PM}_{10}$ up to 4 times on a lantern day (fireworks) in Beijing (China) is found relative to those over normal days [33].

Frequency distribution of $\mathrm{PM}_{2.5}$ mass concentrations over Delhi during study period was also studied (Figure 4). It is divided into nine different categories of $40 \mu \mathrm{g} \mathrm{m}^{-3}$ intervals within the limit of NAAQS from 0 to $360 \mu \mathrm{g} \mathrm{m}^{-3}$. In overall study, mass concentration of $\mathrm{PM}_{2.5}$ skewed toward higher to lower concentrations in respect of corresponding spectrum except $0-40 \mu \mathrm{g} \mathrm{m}^{-3}$ (15\%). The highest contribution was $30 \%$ $\left(40-80 \mu \mathrm{g} \mathrm{m}^{-3}\right)$ followed by $17 \%\left(80-120 \mu \mathrm{g} \mathrm{m}^{-3}\right), 14 \%(120-$ $\left.160 \mu \mathrm{g} \mathrm{m}^{-3}\right), 10 \%\left(160-200 \mu \mathrm{g} \mathrm{m}^{-3}\right), 9 \%\left(200-240 \mu \mathrm{g} \mathrm{m}^{-3}\right)$, $3 \%\left(240-280 \mu \mathrm{g} \mathrm{m}^{-3}\right), 2 \%\left(280-320 \mu \mathrm{g} \mathrm{m}^{-3}\right)$, and $1 \%(320-$ $360 \mu \mathrm{g} \mathrm{m}^{-3}$ ). It clearly indicated that mass concentrations of $\mathrm{PM}_{2.5}$ was higher (85\%) than their National Ambient Air Quality Standard limits $\left(40 \mu \mathrm{g} \mathrm{m}^{-3}\right)$; however, $\sim 30 \%$ of 


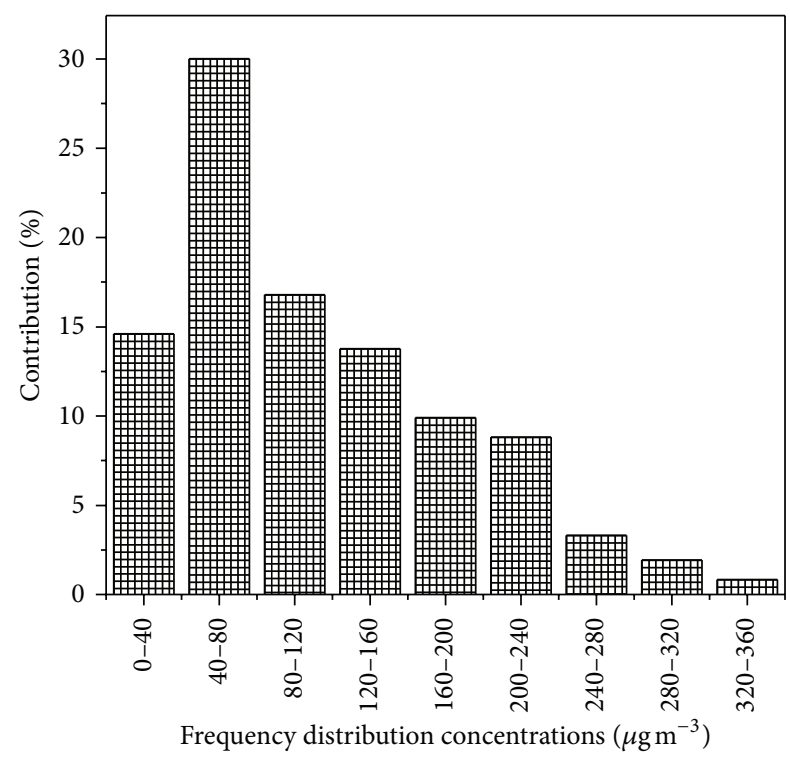

FIGURE 4: Frequency distribution of $\mathrm{PM}_{2.5}$ over Delhi during study period.

samples (significant fraction) were observed between 40 and $80 \mu \mathrm{g} \mathrm{m}^{-3}$ ranges, which indicates that the environment of Delhi is more dangerous in the health point of view due to high loadings of fine particles into the atmosphere of Delhi. This feature is basically due to emissions from anthropogenic sources and climatic conditions of Delhi.

Meteorological parameters such as temperature, relative humidity, wind speed, rainfall, and mixing height play crucial role in dispersion, transportation, and accumulation of the atmospheric pollutants. In general the atmosphere of Delhi during winter season is characterized by low relative humidity and low solar heating of land accompanied by low ventilation coefficients that result in less dispersion of aerosols, which in turn leads to an increase in the concentrations of fine mode particles. Due to this process, there is a greater exposure risk in trapping the air pollutants in the lower layer of the atmosphere thereby resulting in high mass concentrations of PM near to the surface. In such conditions, the probability of the formation of secondary aerosols is higher ([34] and references therein). Apart from this, long range transport of fine particles may also play crucial role during postmonsoon $[24,34]$. Crop harvest and clearing agricultural land by burning the biomass during postmonsoon are common practices in the largely agricultural surroundings. The burning smoke reaches Delhi contributing to substantial smog formation and enhancement in PM and ozone levels [35]. In a recent study, Awasthi et al. [36] reported higher concentrations of $\mathrm{PM}_{2.5}\left(69 \mu \mathrm{g} \mathrm{m}^{-3}\right)$ as compared to NAAQS, which varied from 44 to $147 \mu \mathrm{g} \mathrm{m}^{-3}$ at Patiala district of India, which is located northwest of Delhi near the foothills of the Himalayas. They found that the concentration of fine particulate matter was increased substantially (78\%) during postmonsoon (October to November) due to burning of crop residue with the maxima observed from 100 to $147 \mu \mathrm{g} \mathrm{m}^{-3}$ in 2009. Similar results with higher concentrations of aerosols are also reported by Badarinath et al. [37] using satellitebased measurements during exhaustive burning of rice crop residue in IGP region in the months of October to November. Therefore, the significantly high concentrations of fine size aerosols observed over Delhi have larger influence of certain anthropogenic activities related to agriculture during the winter season [24].

The daily mean mass concentration of PM (108.81 \pm $75.5 \mu \mathrm{g} \mathrm{m}^{-3}$ ) during the study period at Delhi is found to be relatively lower than the previously reported values $\left(171 \mu \mathrm{g} \mathrm{m}^{-3}\right)$ by Khillare et al. [38] during 2004, which can be attributed to introduction of metro-rail and use of CNG for public transport in Delhi. Lowering in the concentrations of $\mathrm{PM}_{2.5}$ may increase in the proportion of petrol-fueled four- and two-wheeler vehicles, three-wheeler converted to $\mathrm{CNG}$, and poor CNG kit in three-wheeler public transport system, which was first generation of CNG three-wheeler vehicles introduced in Delhi. Apart from these, the other significant fallout of the ruling was in the industrial sectorapproximately 500 heavy industries were either shut down or relocated to areas outside the Delhi administrative boundaries. Yet, there remains a tremendous amount of potential to reduce the air pollution impacts in Delhi as the demand rises for infrastructure and services. Reynolds and Kandlikar [39] examined the opportunities for combined benefits of Delhi's fuel switching strategy-not only for local air pollution but also for climate related affects-and evaluated the potential for extending such services to other cities. Gadde et al. [40] have identified the contribution of $\sim 14 \%$ (globally) of the open burnt rice straw in the states of Punjab, Haryana, and Uttar Pradesh. In addition to this, Delhi's low nighttime temperature during the winter $\left(\sim 2^{\circ} \mathrm{C}\right)$ and indoors and outdoors heating of biofuels for heating purpose are accomplished with small coal-burning boilers, stoves, and open burning of leaves and woods [41]. Guttikunda and Calori [42] have done a GIS-based emissions inventory at $1 \mathrm{~km} \times 1 \mathrm{~km}$ spatial resolution for air pollution analysis in Delhi and found the mass concentrations of $\mathrm{PM}_{2.5}\left(123 \pm 87 \mu \mathrm{g} \mathrm{m}^{-3}\right)$ which is higher to present study. Dey et al. [43] have also reported higher outdoor fine particulate $\left(\mathrm{PM}_{2.5}\right)$ mass concentrations $\left(148.4 \pm 67 \mu \mathrm{g} \mathrm{m}^{-3}\right)$ over Delhi. Overall, the level of $\mathrm{PM}_{2.5}$ in Delhi is comparable to Beijing, China $\left(115 \mu \mathrm{g} \mathrm{m}^{-3}\right)$ [44], and to the wintertime in California's San Joaquin Valley, USA $\left(138 \mu \mathrm{g} \mathrm{m}^{-3}\right)$ [45], and is higher than the Belgrade City $\left(75 \mu \mathrm{g} \mathrm{m}^{-3}\right)$ [46].

Recent increase in the proportion of diesel cars and diesel light trucks appears to be the cause of increase of PM concentrations. Besides this, the particulate pollutants in Delhi environment are also contributed to nonexhaust particles originating from wear and corrosion of road pavements, vehicle components, and particles originating in surroundings as well as industrial processes, increasing construction activities, loss of vegetation, and thermal power plants. The four wheelers, which were converted from petrol to compressed natural gas (CNG), are characterized by poor quality of piston rings as well as the improper maintenance of air filters, which generate white smoke, causing increase in PM levels [47]. Apart from generation of particles in the vicinity 
TABLE 1: Yearly mean mass concentrations of $\mathrm{PM}_{2.5}$, temperature, relative humidity, and wind speed along with their standard deviation (std.) and minimum (min) and maximum (max) values in Delhi during 2007 to 2009.

\begin{tabular}{lcccccccccccc}
\hline & \multicolumn{3}{c}{ Mass concentration of $\mathrm{PM}_{2.5}\left(\mu \mathrm{g} \mathrm{m}^{-3}\right)$} & \multicolumn{3}{c}{ Temperature $\left({ }^{\circ} \mathrm{C}\right)$} & \multicolumn{3}{c}{ Relative humidity $(\%)$} & \multicolumn{3}{c}{ Wind speed $(\mathrm{km} / \mathrm{hr})$} \\
Year & 2007 & 2008 & 2009 & 2007 & 2008 & 2009 & 2007 & 2008 & 2009 & 2007 & 2008 & 2009 \\
\hline Mean & 77.5 & 135.4 & 87.1 & 25.4 & 25.1 & 26.0 & 64.2 & 63.9 & 59.1 & 5.0 & 5.2 & 4.7 \\
Std. & 88.8 & 77.8 & 62.2 & 7.0 & 6.5 & 6.9 & 45.9 & 15.2 & 15.9 & 3.4 & 3.5 & 3.9 \\
Max & 367.3 & 367.9 & 345.9 & 39.0 & 35.0 & 37.8 & 88.0 & 97.0 & 97.0 & 18.9 & 18.9 & 19.4 \\
Min & 12.2 & 24.7 & 12.0 & 9.4 & 9.2 & 11.8 & 24 & 25 & 20 & Calm & Calm & Calm \\
\hline
\end{tabular}

of the city, particles from nearby thermal power plants also contribute significantly to the particle level of Delhi. Note that three major power plants, namely, Badarpur, Indraprastha, and Rajghat with the total electricity generation capacity of $1,087 \mathrm{MWs}$, are situated in the vicinity of measurement location. These power plants produce nearly 6,000 metric tons (Badarpur 3,500-4,000, Indraprastha 1,200-1,500, and Rajghat 600-800) of fly ash per day and are responsible for as much as $10 \%$ of the total air pollution load. Furthermore, Delhi is also dealing with massive dust due to continuous constructional activities and a failed effort to control burning of garbage and biomass.

\subsection{Effect of Meteorology on $P M_{2.5}$ Mass Concentrations.} Yearly mean mass concentrations of $\mathrm{PM}_{2.5}$, temperature (Temp.), relative humidity (RH), and wind speed (WS) along with their standard deviation, minimum, and maximum values in Delhi during 2007 to 2009 are assembled in Table 1. Large variations were seen in interannual and intraseasonal (as discussed in Section 3.1) mass concentrations of fine mode particles over Delhi during the study period, which is directly influenced by ambient meteorological conditions. The annual mean mass concentration of $\mathrm{PM}_{2.5}$ during 2008 was higher than in 2007 and 2009, although very good agreement was seen between mass concentrations and meteorological parameters such as WS, temperature, and $\mathrm{RH}$. The highest mean WS $(5.2 \mathrm{Km} / \mathrm{hr})$ was observed in 2008 , whereas the lowest was in $2009(4.7 \mathrm{Km} / \mathrm{hr})$ and the intermediate was in $2007(5.0 \mathrm{Km} / \mathrm{hr})$. Seasonwise occurrence of calm conditions was studied and higher occurrence of calm conditions was observed during winter period of 2008 as compared to 2007 and 2009; however, there are less calm conditions observed in other seasons. The RH was found similar to WS with lower in 2009 (mean RH: 59\%) as compared to 2007 (mean RH: 64\%) and 2008 (mean RH: 63\%). There is no significant relationship seen during interannual variability between mass concentrations with RH; however, good agreement was seen on intraseasonal variability on mass concentrations and RH. Seasonwise variations between them have been studied and higher concentration of fine particles was observed during winter period as in $2007\left(171 \mu \mathrm{g} \mathrm{m}^{-3}\right), 2008\left(163 \mu \mathrm{g} \mathrm{m}^{-3}\right)$, and $2009\left(118 \mu \mathrm{g} \mathrm{m}^{-3}\right)$ and corresponding RH was $72 \%, 62 \%$, and $64 \%$, respectively. In another study, Singh [48] suggested that $\mathrm{RH}$ plays a very crucial role in altering the radiative properties of atmospheric aerosols as hygroscopic nature. A very good agreement between columnar aerosol optical depth and RH over Rajkot was observed by Ranjan et al. [49]. Devara and Raj [50] observed that the higher relative humidity and lower temperature during monsoon period at Pune caused the growth of cloud droplets which results in higher rainfall. In the case of temperature, it was higher during 2009 (Mean: $26^{\circ} \mathrm{C}$ ) compared to 2007 (Mean: $25.4^{\circ} \mathrm{C}$ ) and 2008 (Mean: $25.1^{\circ} \mathrm{C}$ ). Also, large variation was observed between maximum and minimum temperature during interannual variability and varied from 9.4 to $39.0^{\circ} \mathrm{C}$ in $2007,9.2$ to $35.0^{\circ} \mathrm{C}$ in 2008 , and 11.8 to $37.8^{\circ} \mathrm{C}$ in 2009 . Statistically, the variability in temperature was seen during intraseasonal with highest magnitude during summer $\left(31.5^{\circ} \mathrm{C}\right)$ followed by monsoon $\left(31.0^{\circ} \mathrm{C}\right)$, postmonsoon $\left(23.5^{\circ} \mathrm{C}\right)$, and winter $\left(18.0^{\circ} \mathrm{C}\right)$.

Regression analysis between daily mass concentrations of $\mathrm{PM}_{2.5}$ and meteorological parameters such as WS, temperature, and $\mathrm{RH}$ during study period was performed and depicted in Figure 5 (Figure 5(a): WS; Figure 5(b): temperature, and Figure 5(c): RH). Very good agreement was observed between mass concentrations with WS and temperature; however, very week relationships were seen between PM and RH in the overall study due to large variability in $\mathrm{RH}$ during different seasons. A good agreement was seen during intraseasonal which was discussed earlier. Significant correlation between $\mathrm{PM}_{2.5}$ and WS over Delhi was observed $(-0.38(r)$, slope: $Y=6.97725-0.01784 X$; $N=755 ; P<0.0001)$, which is significant at $99 \%$ confidence level (Figure 5(a)). The mass concentrations were separated in different WS (calm conditions and WS $\leq$ $5 \mathrm{Km} / \mathrm{hr}$ and $\geq 5 \mathrm{Km} / \mathrm{hr}$ ). Very high mass concentrations $\left(173.8 \mu \mathrm{g} \mathrm{m}^{-3}\right)$ of PM were observed when WS was in calm conditions; however, when the WS was in $<5 \mathrm{Km} / \mathrm{hr}$, it was still showing higher mass concentration $\left(124.77 \mu \mathrm{g} \mathrm{m}^{-3}\right)$ which is three times higher than NAAQS. Very low PM mass concentrations $\left(79.18 \mu \mathrm{g} \mathrm{m}^{-3}\right)$ were observed in higher WS $(>5 \mathrm{Km} / \mathrm{hr})$. Also, it was seen that the concentrations of pollutants decrease effectively with increasing wind speed, suggesting the dilution of pollutants through dispersion. Similarly to WS, the correlation between PM and temperature was also observed to be very high $(-0.58(r))$, which is also significant at $99 \%$ confidence level (slope: $Y=31.21856-$ $0.05543 X ; N=755 ; P<0.0001$ ) (Figure 5(b)). We also separated the concentrations against temperature (indicated as vertical line) and found that the higher concentrations $\left(164.66 \mu \mathrm{g} \mathrm{m}^{-3}\right)$ were observed when the temperature was less than $22.5^{\circ} \mathrm{C}$; however, very low concentrations $\left(77.14 \mu \mathrm{g} \mathrm{m}^{-3}\right)$ were observed to be $>22.5^{\circ} \mathrm{C}$. Wallace and Kanaroglou [51] studied the relationship between temperature and fine particulate matter during day and night at Ontario, Canada, for the 


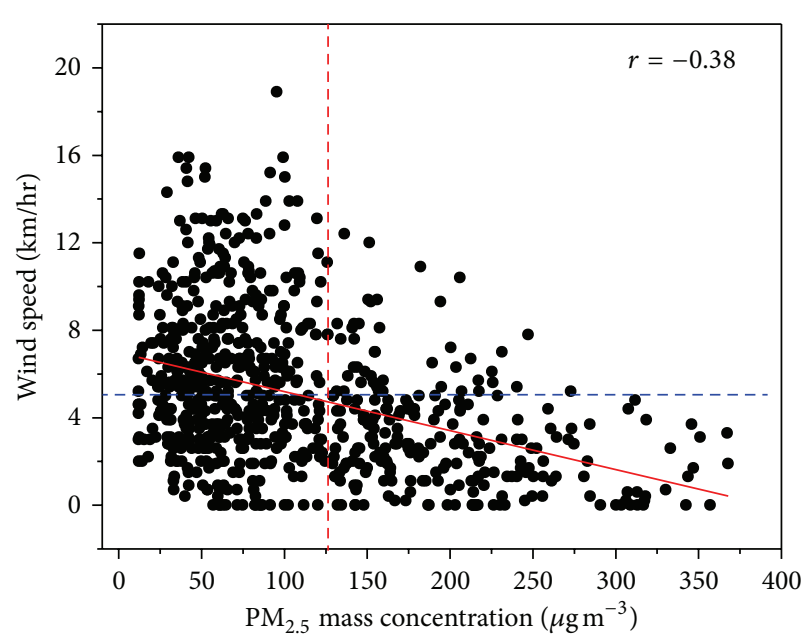

(a)

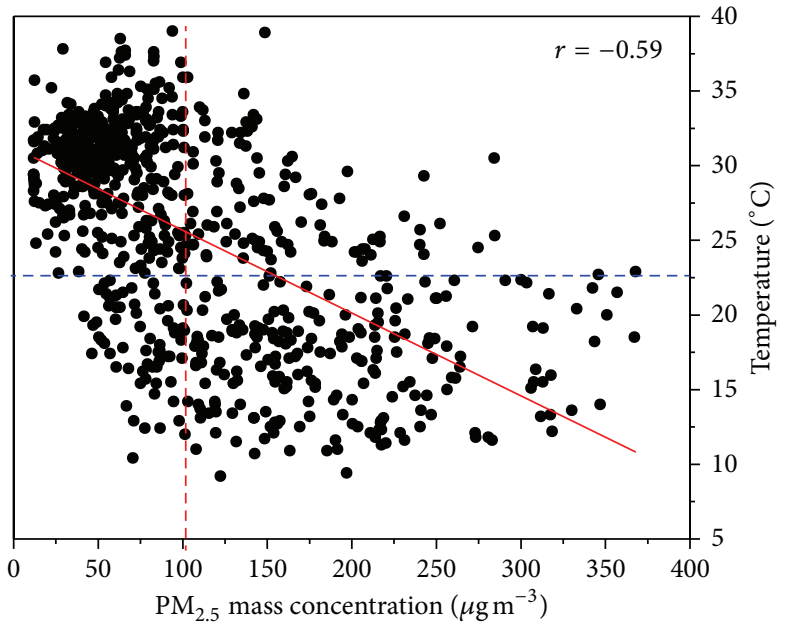

(b)

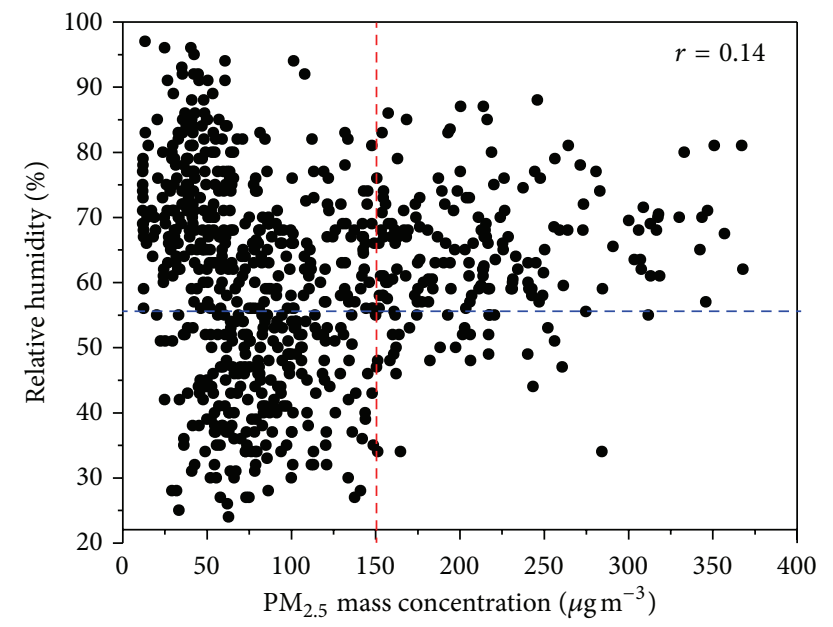

(c)

FIGURE 5: Day to day relation between wind speed and $\mathrm{PM}_{2.5}$ (a), temperature and $\mathrm{PM}_{2.5}$ (b), and relative humidity and $\mathrm{PM}_{2.5}$ (c) during 2007 to 2009. Vertical and horizontal lines indicate the dominance of the metrological parameters and $\mathrm{PM}_{2.5}$ mass concentration.

period from 2003 to 2007. They found that in nighttime, the $54 \%$ concentrations of fine particles increased due to low level inversion and lower temperature but it was found opposite during daytime and the concentration decreased about $14 \%$ during daytime. Due to large variability during day and night temperature along with interannual and intraseasonal variability, very poor relationship (0.14) between $\mathrm{RH}$ and mass concentrations of PM was observed during the study period. Interesting results were seen in the separation of lower $(<55 \%)$ and higher $(>55 \%) \mathrm{RH}$; in case of $<55 \% \mathrm{RH}$, the lower mass concentration $\left(96.96 \mu \mathrm{g} \mathrm{m}^{-3}\right)$ was observed; however, in $>55 \% \mathrm{RH}$, the mass concentration was found to be relatively higher $\left(114.6 \mu \mathrm{g} \mathrm{m}^{-3}\right)$. High wind speed was associated with lower pollutant levels in most of the cases, whereas in the case of $\mathrm{RH}$ and temperature, it was opposite. On the basis of these relationships, it can be mentioned that the interplay of meteorological variables with pollution plays a key role in assessing the impact of pollution for a region. Seasonal correlation analysis between fine particle and meteorological parameters was also performed and depicted in Table 2.
The WS and temperature was found to be negatively correlated during winter and post-monsoon seasons; however, a poor correlation was observed during summer and monsoon. Very interesting results were seen in the case of $\mathrm{RH}$ having positive relationship $(=0.35)$ during postmonsoon whereas significant negative correlation $(-0.48)$ was seen during summer. No relationship was observed during monsoon and winter. It is clearly indicated that meteorological parameters play a vital role in dispersion and accumulation of aerosols in different seasons. Chate and Devara [52] studied the impact of RH on nucleation mode particle during winter of 1997 and 1998 and found that they have positive impact on growth in submicron aerosols $\left(0.013\right.$ to $\left.0.133 \mu \mathrm{g} \mathrm{m}^{-3}\right)$ during cold season; however, during the same period in the present study, we have not found any significant relation in larger particle $\left(2.5 \mu \mathrm{g} \mathrm{m}^{-3}\right)$ as compared to nucleation aerosols. In an other study, Cheng and Lam [53] investigated the impact of wind on TSP concentrations in Hong Kong and found a similar relationship. Also, Chaloulakou et al. [54] investigated the relationship among PM and meteorological parameters such 
TABLE 2: Interannual and intraseasonal correlation coefficient between $\mathrm{PM}_{2.5}$, and meteorological parameters (wind speed: WS, temperature: Temp., and relative humidity: $\mathrm{RH}$ ) in Delhi during 2007 to 2009.

\begin{tabular}{lcccc}
\hline & 2007 & 2008 & 2009 & Overall \\
& $\mathrm{PM}_{2.5}$ & $\mathrm{PM}_{2.5}$ & $\mathrm{PM}_{2.5}$ & $\mathrm{PM}_{2.5}$ \\
\hline WS & -0.30 & -0.56 & -0.30 & -0.38 \\
Temp. & -0.60 & -0.54 & -0.56 & -0.59 \\
RH & 0.03 & 0.11 & -0.01 & 0.14 \\
\hline & Winter & Summer & Monsoon & Postmonsoon \\
& $\mathrm{PM}_{2.5}$ & $\mathrm{PM}_{2.5}$ & $\mathrm{PM}_{2.5}$ & $\mathrm{PM}_{2.5}$ \\
\hline WS & -0.50 & -0.16 & -0.09 & -0.58 \\
Temp. & -0.58 & -0.02 & -0.11 & -0.51 \\
RH & 0.19 & -0.48 & -0.18 & 0.35 \\
\hline
\end{tabular}

as wind speed over Athens, Greece, and found very good agreement with wind speed $(r=-0.43)$ and mass PM. They also found good agreement between temperature and fine particles below $10^{\circ} \mathrm{C}(-0.36)$ and found a positive correlation above $30^{\circ} \mathrm{C}(0.41)$. Further, $\mathrm{PM}_{2.5}$ concentrations measured near a highly trafficked road in Paris were found to be inversely proportional to the wind speed [55].

\section{Conclusions}

Mass concentrations of $\mathrm{PM}_{2.5}$ were collected during three consecutive years over Delhi at a busy traffic intersection at I.T.O., from January 2007 to December 2010. The data were analyzed for annual and seasonal variations of $\mathrm{PM}_{2.5}$ mass concentration and their results are summarized and given below.

The capital of India, Delhi, is found to be heavily loaded with fine particulate matter $\left(\mathrm{PM}_{2.5}\right)$ showing daily mean mass concentration $\left(108.81 \pm 75.5 \mu \mathrm{g} \mathrm{m}^{-3}\right)$ that ranged from 12 to $367.9 \mu \mathrm{g} \mathrm{m}^{-3}$ which is substantially higher than the Indian NAAQS. Approximately $69 \%$ samples of $\mathrm{PM}_{2.5}$ mass were exceeded to $24 \mathrm{~h}$ Indian NAAQS $\mathrm{PM}_{2.5}$ level $\left(60 \mu \mathrm{g} \mathrm{m}^{-3}\right)$ whereas $85 \%$ samples were exceeded to its annual level $\left(40 \mu \mathrm{g} \mathrm{m}^{-3}\right)$. Most of the samples existed between 40 and $80 \mu \mathrm{g} \mathrm{m}^{-3}(\sim 30 \%)$ and indicated that the environment of Delhi is susceptible to a health point of view, generated due to anthropogenic emissions and meteorological conditions over Delhi. Intraseasonal variability of $\mathrm{PM}_{2.5}$ indicates the highest mass concentrations during postmonsoon (154.31 \pm $\left.81.62 \mu \mathrm{g} \mathrm{m}^{-3}\right)$ followed by winter $\left(150.81 \pm 74.65 \mu \mathrm{g} \mathrm{m}^{-3}\right)$, summer $\left(70.86 \pm 29.31 \mu \mathrm{g} \mathrm{m}^{-3}\right)$, and monsoon $(45.06 \pm$ $18.40 \mu \mathrm{g} \mathrm{m}^{-3}$ ). In 2008 , the fine mode particle was $\sim 23 \%$ and $\sim 36 \%$ higher as compared to 2007 and 2009, respectively; these large interannual variations are found due to synoptic meteorological changes. Significant negative correlations are found between $\mathrm{PM}_{2.5}$ and temperature $(-0.59)$ as well as wind speed (-0.38). Higher concentrations of $\mathrm{PM}_{2.5}\left(173.8 \mu \mathrm{g} \mathrm{m}^{-3}\right)$ were observed during calm conditions, whereas $124.77 \mu \mathrm{g} \mathrm{m}^{-3}$ was observed when WS was below $5 \mathrm{Km} / \mathrm{hr}$. Very low PM mass concentrations $\left(79.18 \mu \mathrm{g} \mathrm{m}^{-3}\right)$ were observed in higher WS ( $>5 \mathrm{Km} / \mathrm{hr}$ ). The high correlation is expected due to the cause that concentrations of pollutants decrease effectively with increasing WS and temperature, which suggests the dilution of pollutants into the atmosphere. In winter, greater exposure risk is expected, as the pollutant often gets trapped in lower atmosphere due to stable atmospheric conditions, thereby leading to higher levels. On the basis of the present study, it can be concluded that the interplay of meteorological variables with pollution plays crucial role in assessing the impact of pollution.

\section{Acknowledgments}

The authors gratefully thank Professor B. N. Goswami, Director of the Indian Institute of Tropical Meteorology, Pune for their encouragement and support during the preparation of this paper. Authors also thank the Central Pollution Control Board and the India Meteorological Department for data generation.

\section{References}

[1] S. Dey, S. N. Tripathi, R. P. Singh, and B. Holben, "Influence of dust storms on the aerosol optical properties over the IndoGangetic basin," Journal of Geophysical Research D, vol. 109, no. 20, Article ID D20211, 13 pages, 2004.

[2] S. Singh, S. Nath, R. Kohli, and R. Singh, "Aerosols over Delhi during pre-monsoon months: characteristics and effects on surface radiation forcing," Geophysical Research Letters, vol. 32, no. 13, Article ID L13808, 4 pages, 2005.

[3] G. Pandithurai, S. Dipu, K. K. Dani et al., "Aerosol radiative forcing during dust events over New Delhi, India," Journal of Geophysical Research D, vol. 113, Article ID D13209, 13 pages, 2008.

[4] K. A. Srivastava and S. N. Tripathi, "Numerical study for production of space charge within the stratiform cloud," Journal of Earth System Science, vol. 119, no. 5, pp. 627-638, 2010.

[5] D. W. Dockery and C. A. Pope, "Acute respiratory effects of particulate air pollution," Annual Review of Public Health, vol. 15, pp. 107-132, 1994.

[6] W. P. Anderson, C. M. Reid, and G. L. Jennings, "Pet ownership and risk factors for cardiovascular disease," Medical Journal of Australia, vol. 157, no. 5, pp. 298-301, 1992.

[7] J. Chen, R. P. Wildman, D. Gu et al., "Prevalence of decreased kidney function in Chinese adults aged 35 to 74 years," Kidney International, vol. 68, no. 6, pp. 2837-2845, 2005.

[8] F. Dominici, R. D. Peng, M. L. Bell et al., "Fine particulate air pollution and hospital admission for cardiovascular and respiratory diseases," Journal of the American Medical Association, vol. 295, no. 10, pp. 1127-1134, 2006.

[9] G. E. R. Schwartz, L. G. S. Russek, L. A. Nelson, and C. Barentsen, "Accuracy and replicability of anomalous after-death communication across highly skilled mediums," Journal of the Society for Psychical Research, vol. 65, no. 862, pp. 1-25, 2001.

[10] Y. Wang, C. Lee, S. Tiep et al., "Peroxisome-proliferator-activated receptor $\delta$ activates fat metabolism to prevent obesity," Cell, vol. 113, no. 2, pp. 159-170, 2003.

[11] M. Kandlikar, "The causes and consequences of particulate air pollution in urban India: a synthesis of the science," Annual Review of Energy and the Environment, vol. 25, pp. 629-684, 2000 . 
[12] Central pollution Control Board (CPCB), 2008 Epidemiological study on effect of air pollution on human health (adults) in Delhi. Environmental Health Series: EHS/1/2008, http:// www.cpcb.nic.in.

[13] S. Madronich, "Chemical evolution of gaseous air pollutants down-wind of tropical megacities: Mexico City case study," Atmospheric Environment, vol. 40, no. 31, pp. 6012-6018, 2006.

[14] R. Jaenicke, "Protein folding and Protein Association," Angewandte Chemie, vol. 23, no. 6, pp. 395-413, 1984.

[15] J. W. Milne, D. B. Roberts, S. J. Walk, and D. J. William, "Sources of Sydney brown haze," in The Urban Atmosphere-Sydney. A Case Study, CSIRO, Highett, Australia, 1982.

[16] P. Goyal and S. Sidhartha, "Present scenario of air quality in Delhi: a case study of CNG implementation," Atmospheric Environment, vol. 37, no. 38, pp. 5423-5431, 2003.

[17] A. Kumar and T. C. Foster, "Shift in induction mechanisms underlies an age-dependent increase in DHPG-induced synaptic depression at CA3-CA1 synapses," Journal of Neurophysiology, vol. 98, no. 5, pp. 2729-2736, 2007.

[18] B. Bishoi, A. Prakash, and V. K. Jain, "A comparative study of air quality index based on factor analysis and US-EPA methods for an urban environment," Aerosol and Air Quality Research, vol. 9, no. 1, pp. 1-17, 2009.

[19] V. Kathuria, "Impact of CNG on Delhi's air pollution," Economic and Political Weekly, vol. 40, pp. 1907-1916, 2005.

[20] B. R. Gurjar, J. A. Van Aardenne, J. Lelieveld, and M. Mohan, "Emission estimates and trends (1990-2000) for megacity Delhi and implications," Atmospheric Environment, vol. 38, no. 33, pp. 5663-5681, 2004.

[21] A. Faiz, C. Weaver, K. Sinha, M. Walsh, and J. Carbajo, Air Pollution from Motor Vehicles: Issues and Options for Developing Countries, The World Bank, Washington, DC, USA, 1992.

[22] A. K. Srivastava, S. Singh, S. Tiwari, V. P. Kanawade, and D. S. Bisht, "Variation between near-surface and columnar aerosol characteristics during the winter and summer at Delhi in the Indo-Gangetic Basin," Journal of Atmospheric and SolarTerrestrial Physics, vol. 77, pp. 57-66, 2012.

[23] S. Tiwari, A. K. Srivastava, D. S. Bisht, P. Parmita, M. K. Srivastava, and S. D. Attri, "Diurnal and seasonal variations of black carbon and $\mathrm{PM}_{2.5}$ over New Delhi, India: influence of meteorology," Atmospheric Research, vol. 125-126, pp. 50-62, 2013.

[24] S. Tiwari, D. M. Chate, P. Pragya, K. Ali, and D. S. Bisht, "Variations in mass of the $\mathrm{PM}_{10}, \mathrm{PM}_{2.5}$ and $\mathrm{PM}_{1}$ during the monsoon and the winter at New Delhi," Aerosol and Air Quality Research, vol. 12, no. 1, pp. 20-29, 2012.

[25] S. Tiwari, A. K. Srivastava, D. S. Bisht, and P. D. Safai, "Assessment of carbonaceous aerosol over Delhi in the IndoGangetic Basin: characterization, sources and temporal variability," Natural Hazards, vol. 65, pp. 1745-1764, 2013.

[26] S. Tiwari, D. M. Chate, M. K. Srivastava et al., "Statistical evaluation of $\mathrm{PM}_{10}$ and distribution of $\mathrm{PM}_{1}, \mathrm{PM}_{2.5}$, and $\mathrm{PM}_{10}$ in ambient air due to extreme fireworks episodes (Deepawali festivals) in megacity Delhi," Natural Hazards, vol. 61, no. 2, pp. 521-531, 2012.

[27] A. K. Attri, U. Kumar, and V. K. Jain, "Formation of ozone by fireworks," Nature, vol. 411, no. 6841, pp. 1015-1021, 2001.

[28] R. P. Singh, S. Dey, and B. Holben, "Aerosol behaviour in Kanpur during Diwali festival," Current Science, vol. 84, no. 10, pp. 13021303, 2003.
[29] S. C. Barman, R. Singh, M. P. S. Negi, and S. K. Bhargava, "Fine particles $\left(\mathrm{PM}_{2.5}\right)$ in ambient air of Lucknow city due to fireworks on Diwali festival," Journal of Environmental Biology, vol. 30, no. 5, pp. 625-632, 2009.

[30] W. Bach, A. Daniels, L. Dickinson et al., "Firework's pollution and health," International Journal of Environmental Studies, vol. 7, pp. 183-192, 1975.

[31] B. Wehner, A. Wiedensohler, and J. Heintzenberg, "Submicrometer aerosol size distributions and mass concentration of the Millennium fireworks 2000 in Leipzig, Germany," Journal of Aerosol Science, vol. 31, no. 12, pp. 1489-1493, 2000.

[32] D. Liu, D. Rutherford, M. Kinsey, and K. A. Prather, "Real-time monitoring of pyrotechnically derived aerosol particles in the troposphere," Analytical Chemistry, vol. 69, no. 10, pp. 18081814, 1997.

[33] Y. Wang, G. Zhuang, C. Xu, and Z. An, "The air pollution caused by the burning of fireworks during the lantern festival in Beijing," Atmospheric Environment, vol. 41, no. 2, pp. 417-431, 2007.

[34] A.-P. Hyvärinen, H. Lihavainen, M. Komppula et al., "Aerosol measurements at the Gual Pahari EUCAARI station: preliminary results from in-situ measurements," Atmospheric Chemistry and Physics, vol. 10, no. 15, pp. 7241-7252, 2010.

[35] NASA (National Aeronautics and Space Administration), Top Science, Exploration and Discovery Stories of 2008.

[36] A. Awasthi, R. Agarwal, S. K. Mittal, N. Singh, K. Singh, and P. K. Gupta, "Study of size and mass distribution of particulate matter due to crop residue burning with seasonal variation in rural area of Punjab, India," Journal of Environmental Monitoring, vol. 13, no. 4, pp. 1073-1081, 2011.

[37] K. V. S. Badarinath, T. R. K. Chand, and V. K. Prasad, "Agriculture crop residue burning in the Indo-Gangetic Plains: a study using IRS-P6 AWiFS satellite data," Current Science, vol. 91, no. 8, pp. 1085-1089, 2006.

[38] P. S. Khillare, T. Agarwal, and V. Shridhar, "Impact of CNG implementation on PAHs concentration in the ambient air of Delhi: a comparative assessment of pre- and post-CNG scenario," Environmental Monitoring and Assessment, vol. 147, no. 1-3, pp. 223-233, 2008.

[39] C. C. O. Reynolds and M. Kandlikar, "Climate impacts of air quality policy: switching to a natural gas-fueled public transportation system in New Delhi," Environmental Science and Technology, vol. 42, no. 16, pp. 5860-5865, 2008.

[40] B. Gadde, S. Bonnet, C. Menke, and S. Garivait, "Air pollutant emissions from rice straw open field burning in India, Thailand and the Philippines," Environmental Pollution, vol. 157, no. 5, pp. 1554-1558, 2009.

[41] K. Ali, G. A. Momin, S. Tiwari, P. D. Safai, D. M. Chate, and P. S. P. Rao, "Fog and precipitation chemistry at Delhi, North India," Atmospheric Environment, vol. 38, no. 25, pp. 4215-4222, 2004.

[42] S. K. Guttikunda and G. Calori, "A GIS based emissions inventory at $1 \mathrm{~km} \times 1 \mathrm{~km}$ spatial resolution for air pollution analysis in Delhi, India," Atmospheric Environment, vol. 67, pp. 101-111, 2013.

[43] S. Dey, L. D. Girolamo, A. V. Donkelaar, S. N. Tripathi, T. Gupta, and M. Mohan, "Variability of outdoor fine particulate $\left(\mathrm{PM}_{2.5}\right)$ concentration in the Indian Subcontinent: a remote sensing approach," Remote Sensing of Environ, vol. 127, pp. 153-161, 2012.

[44] K. He, F. Yang, Y. Ma et al., "The characteristics of $\mathrm{PM}_{2.5}$ in Beijing, China," Atmospheric Environment, vol. 35, no. 29, pp. 49594970, 2001. 
[45] J. G. Watson, "Visibility: science and regulation," Journal of the Air and Waste Management Association, vol. 52, no. 6, pp. 628713, 2002.

[46] S. F. Rajšić, M. D. Tasić, V. T. Novaković, and M. N. Tomašević, "First assessment of the $\mathrm{PM}_{10}$ and $\mathrm{PM}_{2.5}$ particulate level in the ambient air of Belgrade City," Environmental Science and Pollution Research, vol. 11, no. 3, pp. 158-164, 2004.

[47] EPCA report number 9 (November 2004) Report on the increase in the number of three-wheelers in Delhi, In response to the Hon'ble Supreme Court Order Dated October 8, 2004, In response to the I.A. 217 of 2003.

[48] N. Singh, Role of atmospheric ions on condensation and cloud formation processes [Ph.D. thesis], University of Roorkee, Roorkee, India, 1985.

[49] R. R. Ranjan, H. P. Joshi, and K. N. Iyer, "Spectral variation of total column aerosol optical depth over Rajkot: a tropical semiarid Indian station," Aerosol and Air Quality Research, vol. 7, no. 1, pp. 33-45, 2007.

[50] P. C. S. Devara and P. E. Raj, "A lidar study of atmospheric aerosols during two contrasting monsoon seasons," Atmosfera, vol. 11, no. 4, pp. 199-204, 1998.

[51] J. Wallace and P. Kanaroglou, "The effect of temperature inversions on ground-level nitrogen dioxide $\left(\mathrm{NO}_{2}\right)$ and fine particulate matter $\left(\mathrm{PM}_{2.5}\right)$ using temperature profiles from the Atmospheric Infrared Sounder (AIRS)," Science of the Total Environment, vol. 407, no. 18, pp. 5085-5095, 2009.

[52] D. M. Chate and P. C. S. Devara, "Growth properties of submicron aerosols during cold season in India," Aerosol and Air Quality Research, vol. 5, no. 2, pp. 127-140, 2005.

[53] S. Cheng and K. Lam, "An analysis of winds affecting air pollution concentrations in Hong Kong," Atmospheric Environment, vol. 32, no. 14-15, pp. 2559-2567, 1998.

[54] A. Chaloulakou, P. Kassomenos, N. Spyrellis, P. Demokritou, and P. Koutrakis, "Measurements of $\mathrm{PM}_{10}$ and $\mathrm{PM}_{2.5}$ particle concentrations in Athens, Greece," Atmospheric Environment, vol. 37, no. 5, pp. 649-660, 2003.

[55] S. Ruellan and H. Cachier, "Characterisation of fresh particulate vehicular exhausts near a Paris high flow road," Atmospheric Environment, vol. 35, no. 2, pp. 453-468, 2001. 

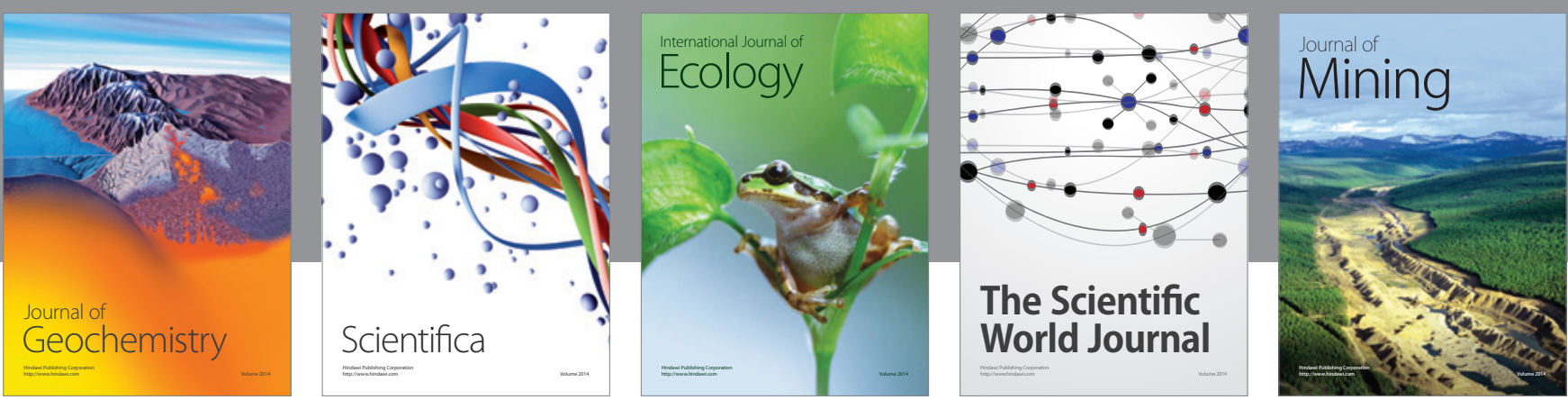

The Scientific World Journal
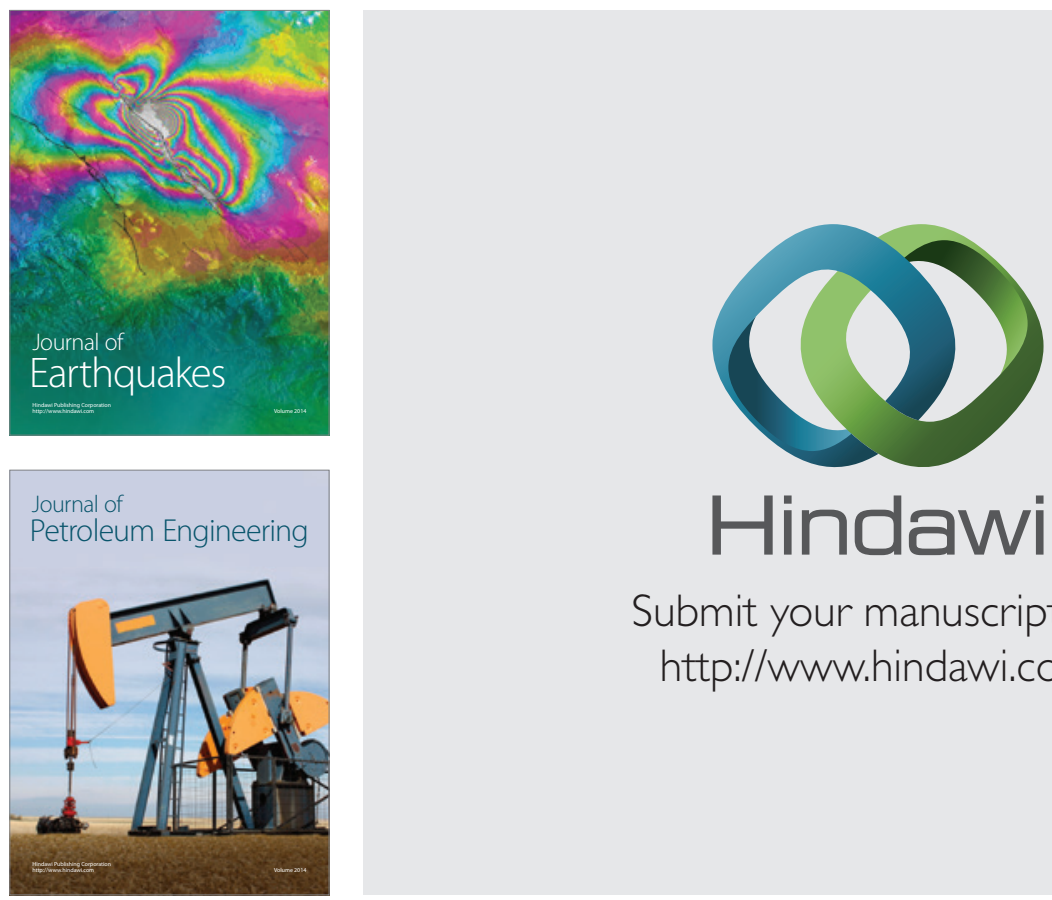

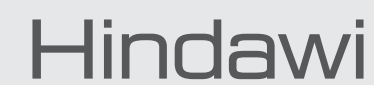

Submit your manuscripts at

http://www.hindawi.com
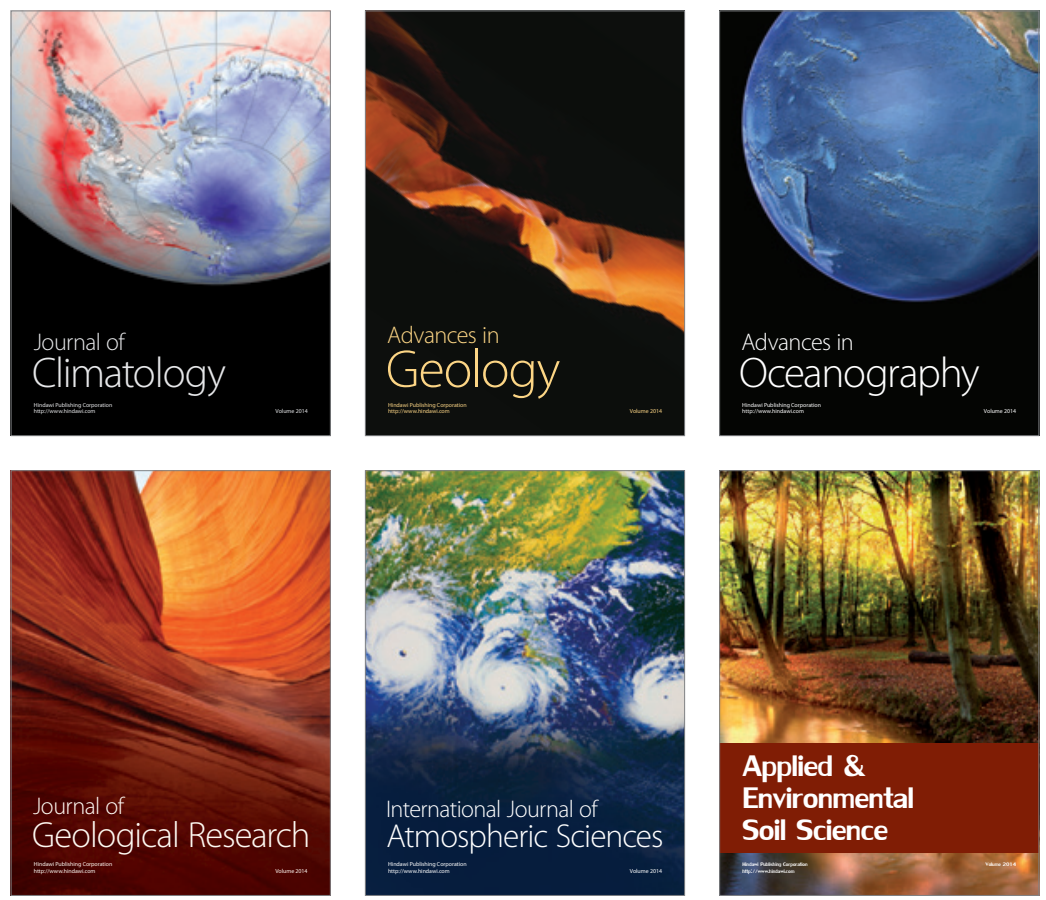
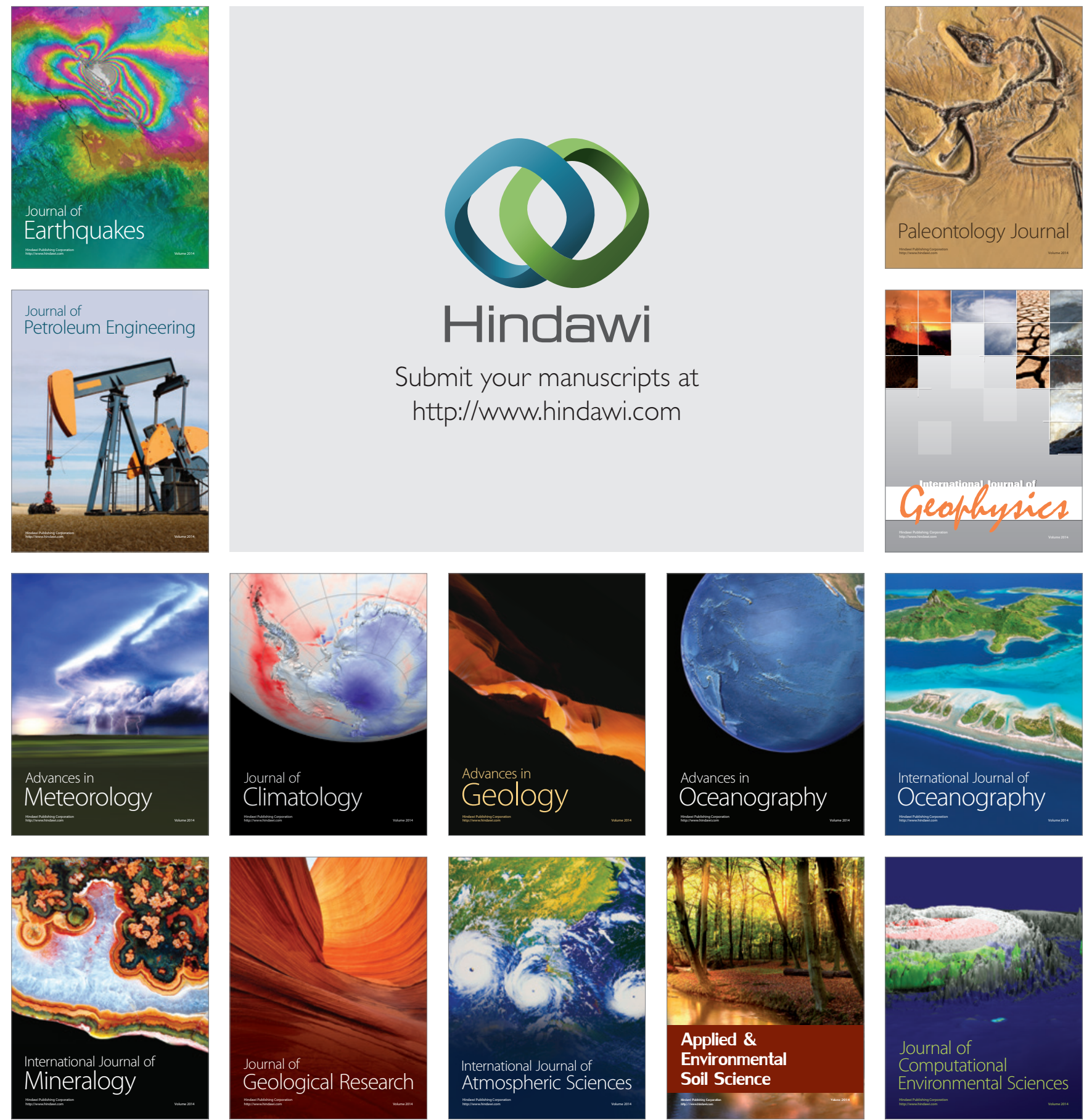